\title{
熱環境からみた冬期の居住性能に関する地域特性の推移 \\ 一東北地方都市部を対象とした 36 年間の変化一 \\ REGIONAL CHARACTERISTIC TRANSITIONS OF WINTER THERMAL PERFORMANCE AND OCCUPANT BEHAVIOR OF DETACHED HOUSES IN TOHOKU CITY AREAS OVER 36 YEARS
}

\author{
長谷川兼一 ${ }^{* 1}$, 増田早也花 ${ }^{* 2}$, 吉 野 博*3, 松 本 真 ${ }^{* 1}$, 竹 内 仁 哉 ${ }^{* 4}$ \\ Kenichi HASEGA WA, Sayaka MASUDA, Hiroshi YOSHINO, \\ Shin-ichi MATSUMOTO, and Jinya TAKEUCHI
}

\begin{abstract}
The indoor thermal environments, energy consumption, and occupant behavior of 587 detached houses in Tohoku region were surveyed during the winter of 2018 through a questionnaire. Similar investigations have been performed at 10-year intervals since 1982. The purpose of this study is to gain a better understanding of changes to indoor thermal environment and energy consumption trends in such houses. From the results, it was determined that the thermal performance levels in Tohoku City areas were becoming similar to those of similar dwellings in Sapporo and that differences have been lessening over the last 36 years in all surveyed municipalities.
\end{abstract}

Keywords: Detached Houses, Thermal Environment, Questionnaire Survey, Room Temperature, Muitivariate Analysis 戸建住宅, 熱環境, アンケート調査, 室温, 多変量解析

\section{1.はじめに}

近年，地球環境問題に対する関心の高まりとともに，我が国の住 宅性能は向上しつつあり, 高効率な住宅設備の普及や省エネルギー 家電の浸透により, 室内の熱・空気環境などの居住環境も数十年間 で大きく変化していると推察される。筆者らは, 1982 年から 10 年毎 に東北地方 12 都市を中心とした約 1,000 戸の住宅を対象として, 熱 環境からみた冬期の居住性能 (以後, 居住性能) 注1) に関するアン ケート調查と液晶温度計を用いた室温調查を実施してきた ${ }^{1) ~ 3)}$ 。最初 の調查から 30 年目になる 2012 年にも調査を試みたが, 調査対象に 東日本大震災の影響を受けた都市が半数近く含まれていたため, 震 災被害から間もない時期での対応が難しく, 当初計画していた協力 を得ることが困難であった。その結果, 規模を縮小して調查を進めざ

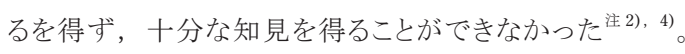

既に筆者らは, 2002 年までの調査結果をもとに, 東北地方 12 都 市の居住性能の特徵や地域特性, 1982 年の調査から 20 年間の変 化について明らかにし, 断熱気密性能に代表されるシェルター性能 や暖房環境に対する配慮が十分にされていない状態では, 一世帯 当たりのエネルギー消費量が増大寸る可能性があることを指摘 ${ }^{3)} し て ~$ いる。今後, 住宅の省エネルギー基準への適合が促進されるととも
に, ゼロ・エネルギー建築が浸透 ${ }^{5)}$ するものと期待されるが，現時 点での居住性能の実態を, これまでの推移と照らし合わせながら把 握することは, 我が国の住宅政策のあるべき姿を提示するための基 礎的資料となり意義深いと考える。

そこで, 過去の調査と同様に, 東北地方各都市と札幌, 府中を対 象としたアンケート調查と液晶温度計による室温調查を 2018 年冬期 に実施した。1982 年に実施した最初の調查から 36 年を迎える年で はあるが, 冬期の居住性能の変化として住宅性能, 室内環境, エネ ルギー消費量などの地域特性を分析した結果, 興味深い傾向が見ら れたので報告する。

\section{2. 調査概要}

\section{1 対象都市と調査期間}

Table 1 に対象都市, 対象住戸数, 調査期間中の平均外気温を 示す。外気温は最寄りの気象観測所のデータを参照した。調查期間 は 2018 年 2 月 2 日〜 8 日の 1 週間である。これまでの筆者らの一 連の調查では, 調查地域の教育委員会や小学校の協力を得ながら, 小学校 5 年生の児童の自宅を調查対象としていた。しかしながら, 個人情報保護等の観点から, 従前のような調查標本を確保するプロ

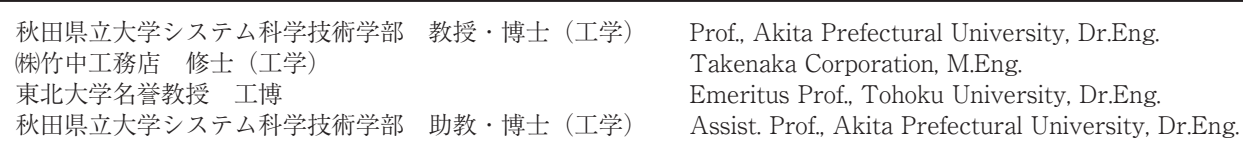

Prof., Akita Prefectural University, Dr.Eng.

Takenaka Corporation, M.Eng.

Emeritus Prof., Tohoku University, Dr.Eng.

Assist. Prof., Akita Prefectural University, Dr.Eng. 
セスを遂行することが極めて困難であったため, 今回の調查ではイ ンターネットを活用したアンケート調查とし，一部の住宅に室温調査 を依頼した。また，東北地方の各都市においては，有効なサンプ ルの確保を優先するために, 人口が集中している県庁所在地のみを 調查対象とした。本研究では, 比較対照として, 東北地方よりも寒 冷な札幌と温暖な府中を選び，それら合わせて合計 8 都市注3) を調 查対象とした。

\section{2 調査方法と内容}

調査に当たっては, インターネット調査会社の顧客リスト 注4) から, 調查対象の条件に見合う住宅を確保するために事前調查を実施し た。調査対象の条件として, 過去の調查結果と比較が可能なように 戸建住宅とし, (1)灯油暖房を使用, (2)小学校高学年の児童と同居, する世帯を設定した。これまでの調查と同程度になるように，各都市 の標本数を 60 世帯以上として協力を募った。なお，標本数が目標 に満たない場合は，上記 (1)，(2)の条件を緩和し，電気を熱源とす る暖房器具の使用と小中学校の児童・生徒と同居する世帯も含め た。その結果, 事前調查の段階で条件に見合う 737 世帯に対して 587 世帯の有効回答 (回収率 79.6\%) を得た。なお，インターネット 調査では標本の妥当性が懸念されるが，例えば，各都市の調査対 象の年間収入を総務省による統計值 ${ }^{6)}$ と比較すると大きく乘離して おらず，地域を代表させるために適切な標本であると判断している。

アンケート調査の内容をTable 2 に示寸。質問内容は，住宅の 熱環境からみた居住性能が評価できるよう, 温熱環境と室内空気環 境, 住宅設備, 住まい方, シェルター性能, エネルギー消費量, 居住者特性に関わる項目の 41 項目で構成されている。室温調査で は，各都市の住宅 10 世帯を対象とすることを原則として，調查開 始時に液晶温度計注5) を対象住宅に配布し，居間と寝室のそれぞれ に，床上 $1 \mathrm{~m}$ の柱や壁に設置してもらった。室温の測定では，起床 時 ( 以後, 朝と呼ぶ) と夕食後の団らん時 (以後, 夜と呼ぶ ) の 1 日 2 回， 1 週間にわたって温度の読み取りと記録を依頼した。

\section{3. 調査結果と 36 年間の比較}

\section{1 温熱環境に関するアンケート調査結果}

アンケート調査の主な結果を都市別に集計し Fig.1 に示す。以下 に，前回までの結果 ${ }^{1)>3)}$ と比較し考察する。

\section{(1)住宅規模}

全体の床面積の平均值は $131.3 \mathrm{~m}^{2}$ であり, 2002 年の調査結 果からの変化が小さい。また，府中については他の都市よりも $「 60 \sim 100 \mathrm{~m}^{2} 」 の$ 割合が高く，前回の結果と同様である。

\section{(2)断熱性能}

断熱材の使用割合は全体で $70.0 \%$ であった。2002 年の調査では $76.6 \%$ であったが，今回は「不明」との回答が全体の $22.0 \%$ と割合 が高くなった。空ガラスの枚数では,「二枚ガラス」の割合が高く半 数以上を占めているが, 仙台, 山形, 府中は, 他の都市に比べて 「一枚ガラス」の割合が高いため，ガラスの種類については地域間 で差が見られる。2002 年の調查の時点では「二枚ガラス」の割合 が増加したことを確認したが，現時点においても，前回と比べても各 都市で「二枚ガラス」の割合が高くなっている。全体的に断熱性能 の高い住宅が増加していることが窺える。

空ガラスと空枠の組み合わせにより住宅の断熱水準を推定 ${ }^{7)}$ し,
Table 1 Surveyed areas and no. of respondents

\begin{tabular}{l|ccccccc}
\hline $\begin{array}{c}\text { Surveyed } \\
\text { area }\end{array}$ & $\begin{array}{c}\text { No. of } \\
\text { recruited } \\
\text { subjects }\end{array}$ & $\begin{array}{c}\text { No. of } \\
\text { respondents }\end{array}$ & \multicolumn{2}{c}{$\begin{array}{c}\text { No. of } \\
\text { indooor } \\
\text { temp. meas. }\end{array}$} & \multicolumn{4}{c}{$\begin{array}{c}\text { Outdoor temp. during } \\
\text { surveyed period }\left[{ }^{\circ} \mathrm{C}\right]\end{array}$} \\
\hline Sapporo & 91 & 80 & 12 & -4.0 & -0.7 & -2.6 & -3.8 \\
Aomori & 88 & 79 & 12 & -0.7 & 0.8 & -0.8 & -3.4 \\
Morioka & 80 & 79 & 12 & -1.9 & -0.1 & -1.6 & -0.3 \\
Sendai & 88 & 70 & 12 & -0.8 & 4.0 & 1.5 & 2.1 \\
Akita & 93 & 75 & 9 & -0.1 & 0.0 & -1.1 & -1.5 \\
Yamagata & 112 & 75 & 10 & 1.6 & 1.9 & -0.2 & 1.2 \\
Fukushima & 86 & 68 & 11 & 1.2 & 3.9 & 3.0 & -0.2 \\
Fuchu & 99 & 61 & 11 & 2.6 & 6.2 & 6.2 & 3.8 \\
\hline Total & 737 & 587 & 89 & & & & \\
\hline
\end{tabular}

Table 2 Questionnaire contents

\begin{tabular}{|c|c|}
\hline Factor & Item \\
\hline $\begin{array}{l}\text { Thermal environment } \\
\text { and IAQ } \\
\text { (13 items) }\end{array}$ & $\begin{array}{l}\text { Living room temperature in the morning and evening; } \\
\text { Bedroom temperature in the morning and evening; Draft } \\
\text { in a living room; Indoor thermal comfort in the morning; } \\
\text { Perception of indoor air contamination; Perception of } \\
\text { indoor dryness; Health damage from indoor air } \\
\text { contamination; Condensation in each room (living room, } \\
\text { bed room, washroom and lavatory); Place of } \\
\text { condensation occurrence; Degree of condensation } \\
\text { occurrence; Frequency of condensation occurrence }\end{array}$ \\
\hline $\begin{array}{l}\text { Equipment } \\
\text { ( } 3 \text { items) }\end{array}$ & $\begin{array}{l}\text { Heating equipment in a living room and bedroom; } \underline{\text { Housing }} \\
\text { equipment (ventilation system, hot water supply etc.) }\end{array}$ \\
\hline $\begin{array}{l}\text { Occupants behavior } \\
\text { ( } 7 \text { items) }\end{array}$ & $\begin{array}{l}\text { Pattern of heating time in a living room and bedroom; } \\
\text { Heating period; Clothing of male and female; } \\
\text { Countermeasures against condensation; } \\
\text { Countermeasures against indoor air contamination }\end{array}$ \\
\hline $\begin{array}{l}\text { Shelter performance } \\
\text { (10 items) }\end{array}$ & $\begin{array}{l}\text { Completion; Floor area; Construction; Thermal insulation; } \\
\text { Thermal insulation retrofit; Sunshine condition; Window } \\
\text { sash; Window pane; Living room floor components; Draft } \\
\text { in a living room }\end{array}$ \\
\hline $\begin{array}{l}\text { Energy consumption } \\
\text { ( } 4 \text { items) }\end{array}$ & $\begin{array}{l}\text { Monthly consumption of electricity; Kerosene consumption } \\
\frac{\text { during winter; Kerosene consumption on January; Usage }}{\text { of kerosene }}\end{array}$ \\
\hline $\begin{array}{l}\text { Household information } \\
\text { (4 items) }\end{array}$ & $\begin{array}{l}\text { All residing family members; Age of each family member; } \\
\text { Annual income; Occupation }\end{array}$ \\
\hline
\end{tabular}

* Underline means items used in the multilevel analysis (chapter 4).

過去の省エネルギー基準に分類したが，「1980 年基準相当」「1992 年基準相当」が大半を占めている。青森, 盛岡, 秋田, 山形では,

「1992 年基準相当」の割合が最も高いが，その他の東北地方の各 都市では「1980 年基準相当」の割合の方が高く, 断熱性能の分 布に地域性が見られる。また,「1999 年基準相当」の断熱性能を 有する住宅は全体の $5.6 \%$ 程度に留まっている。

\section{(3)居間の暖房器具と暖房時間}

使用暖房器具について，2002 年の調查までは札幌と東北地方で 主に使用されていた「FF 式石油ストーブ」「石油ファンヒータ」に 代わって,「エアコン」の使用割合が増加しており, 状況が変化し ている。2002 年の調查では, 北東北各都市の約 $50 \%$ 世帯で「FF 式石油ストーブ」が使用されていたが，今回は $20 \%$ 以下となった。 また, 盛岡, 仙台, 福島では, 「石油ファンヒータ」の使用割合が $19.8 \sim 31.3 \%$ を占めており, 2002 年の調查での使用割合 $(27.1 \sim$ 47.3\%) よりも低下している。札幌ではこれまでの調查と大差なくセン トラル暖房の割合が高く, 東北地方では蓄熱暖房器を使用する住宅 も見られる。東北地方においても「こたつ」の使用割合は低下して おり， 2002 年の調查では福島で $52.7 \%$ が使用していたが，今回は $17.9 \%$ とその半分以下になっている。

暖房時間は, 札幌, 青森, 盛岡, 秋田で「終日」または「起床 


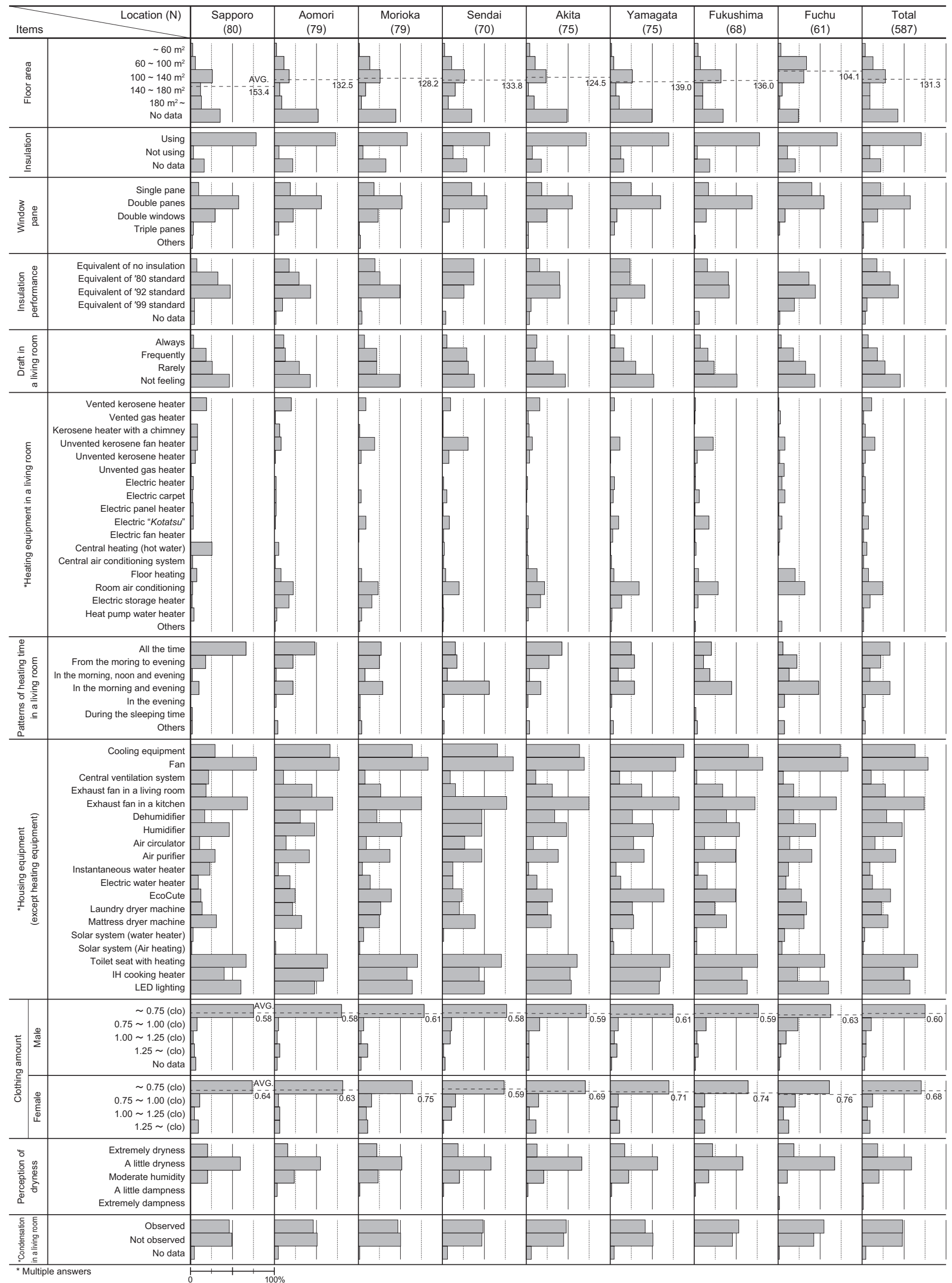

Fig.1 Housing characteristics, occupant behavior and indoor environment at each surveyed area 
一就寝」の割合が高く, 仙台, 福島, 府中では「朝, 夕食一就寝」 の割合が高い。また，札幌市と東北地方では「終日」暖房する割 合が 2002 年の調查よりも高くなっているため, 全体的に暖房時間が 増加していると推察される。

\section{(4)各種住宅設備の保有状況}

暖房器具以外の住宅設備では, 「冷房設備」,「セントラル式換気 設備」,「除湿器」,「空気清浄機」などで地域的な差がみられる。「冷 房設備」は南下寸るにつれ保有率は高くなるが, 府中で $75.4 \%$, 仙台で $67.1 \%$ となっており, 2002 年の調査結果と比べて減少してい る。 2002 年の調查では, 札幌での「冷房設備」の保有率は数 \% であったが，今回は $28.8 \%$ まで増加した。

「セントラル式換気設備」は札幌で保有率が高く, 全都市におい て 2002 年の調查結果と比べてもその割合は増加している。これは, 2003 年以降の換気設備設置の義務化に伴い, それ以降に建設さ れた住宅での保有状況が影響したと考えられる。

「除湿器」や「空気清浄機」は, 仙台や福島で保有率が高い。 「空気清浄機」については, 前回の調查よりも保有率が増加してお り, 仙台, 福島, 府中では 40.0 - 50.0\%の世帯が保有している。 「ヒータ付便座」の保有率は全体で $67.1 \%$ であるが, 前回と比べて 大差ない。また, 2002 年までの調査では, 「ふとん乾燥機」の保 有率が東北地方の平均で $45.8 \%$ であったが, 現時点では, 25.3 $40.0 \%$ に留まっている。

\section{(5)団らん時の着衣量}

過去の調查と同様に, 団らん時の着衣量には明確な地域性を確 認することはできない。また， 2002 年の調査結果と同様に男女間の 差も小さいが, 主人と主婦とも $0.75 \mathrm{c} 10$ 未満と回答する割合が増加 しており，全体的に薄着傾向にある。

\section{(6)空気の乾燥}

2002 年の調査では, 「ちようど良い」との回答は全体の $43.1 \%$ で あったが, 今回は $20.4 \%$ 程度に減少している。逆に,「やや乾燥し ている」割合が増加しており, 全体の $77.7 \%$ 前後の居住者が乾燥 側 (「非常に乾燥している」と「やや乾燥している」) に申告している。 これは, 水蒸気を発生しない密閉型ストーブやエアコンの使用割合 が増加したこと, 住宅内の温度が高く保たれるようになり相対湿度が 低下したことも影響していると推察される。

\section{(7)居間の結露}

居間の空ガラスや壁面等での結露の有無を尋ね, そのいずれか で「結露あり」と回答した割合は全体の $48.2 \%$ であり, 2002 年の 調查 $(55.2 \%)$ よりも 7.0 ポイント減少した。 2002 年の調查では, 南 下寸るほど「結露はしない」と回答する割合が低くなっていたが， 今回は地域差がほとんど見られなくなった。特に, 札幌や青森で は, 結露「あり」の割合が増加しており, 前回 ( 札幌 $34.8 \%$, 青森 32.7\%) よりもそれぞれ 11.5 ポイント, 12.9 ポイント高くなっている。 また，本論文には示していないが，各都市とも結露する部位は空ガ ラスの表面と空枠の表面が大半を占めている。

\section{2 各都市における暖房エネルギー消費量}

Fig. 2 に過去 3 回の調查結果とともに, 今回の調查にて得られた 各都市における一冬の 1 世帯当たりの灯油消費量の平均值と, 各 都市における各住宅の灯油もしくは電気を熱源とした暖房のエネル ギー消費量 ${ }^{(i \pm}$ 6) 示す。なお，電気については二次エネルギー消

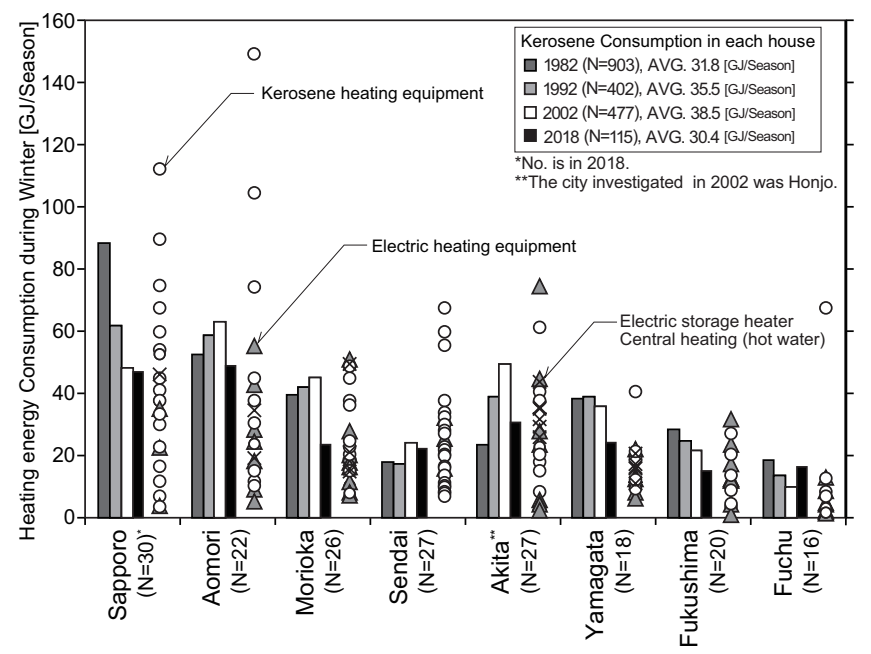

Fig.2 Energy consumption for space heating

費量として表示している。

2002 年の調查までは灯油消費量が年々増加している都市が大半 であったが, 札幌市では減少傾向にあった。この理由として北海道

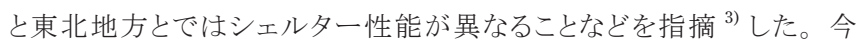
回の調查においては東北地方においても灯油消費量が 2002 年より も減少している。先に触れた 2012 年に実施した同様の調查におい ても東北地方の調查対象都市の灯油消費量がやや減少傾向注2), 4) にあるため, これらの調查結果は整合している。今回の調査におい て確認された灯油消費量の減少傾向には, 空ガラスの種類の変化 にて確認されたように, シェルター性能の向上による影響が反映され ている可能性がある。

今回の調査では, 暖房に電気を熱源とするエネルギー消費量も含 めており, 二次エネルギーとして表現すると灯油消費量のばらつき の範囲に収まっている。熱源の区別なく, 住宅ごとの暖房エネルギー 消費量に着目すると, それらのばらつきは非常に大きいことが示され る。本論文には示していないが, 床面積や暖房時間もばらつきの要 因の一つであるものの, それら以外の要因の影響も無視できないこ とを確認している。

\section{3 各都市における室温}

Fig. . に各都市における朝と夜の居間温度を過去の調査結果とと もに示す。 2018 年の調查では, 朝の居間温度 (Fig.3(a)) におけ る各都市の全住宅の平均值は $17.1^{\circ} \mathrm{C}$ である1982 年の調查では $10.2^{\circ} \mathrm{C}, 1992$ 年では $14.0^{\circ} \mathrm{C}, 2002$ 年では $16.2^{\circ} \mathrm{C}$ あ゙あことから, 朝の居間温度は上昇傾向にあるといえる。しかしながら, 2018 年の 結果は, 2002 年の調查結果との差が小さくなっており, 上昇傾向は 頭打ちになりつつある。また, 標準偏差は小さくなっているものの, 依然として各都市での住戸間のばらつきは大きい。

夜の時間帯では, 大半の世帯で暖房を運転していると考えられ るが，2018 年の調查における居間温度 (Fig.3(b))の全体の平 均值は $20.5^{\circ} \mathrm{C}$ である。1982 年の調查では $17.9^{\circ} \mathrm{C}, 1992$ 年では $19.9^{\circ} \mathrm{C}, 2002$ 年では $20.0^{\circ} \mathrm{C}$ であり若干上昇傾向にある。しかしな がら, 朝の居間温度とは傾向が異なり, 調查年ごとの都市間の差は 小さくなっている。また, 標準偏差は全ての都市で小さく, 暖房時 間帯における住戸間のばらつきは, 朝の居間温度と比べると小さく なりつつある。 
(a) Morning

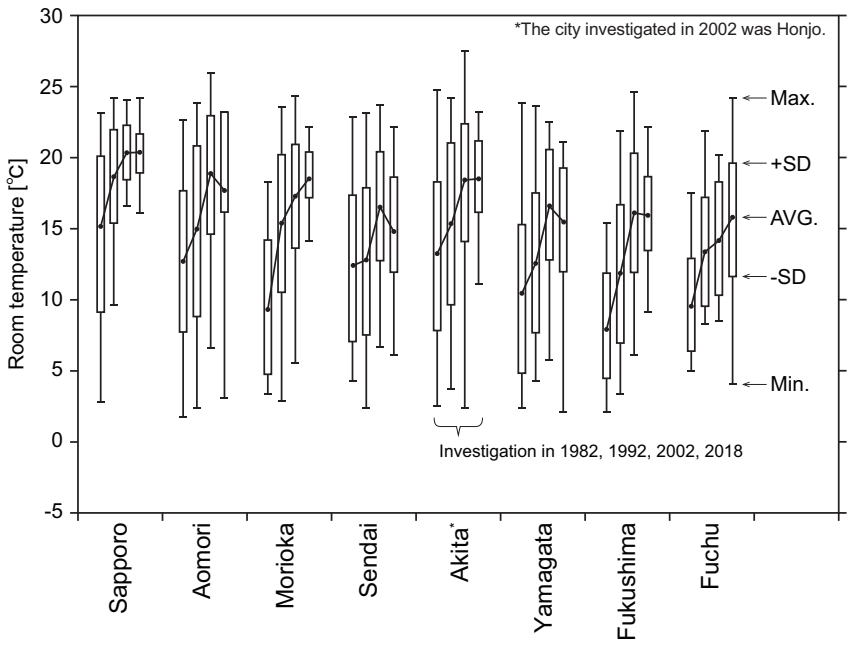

(b) Evening

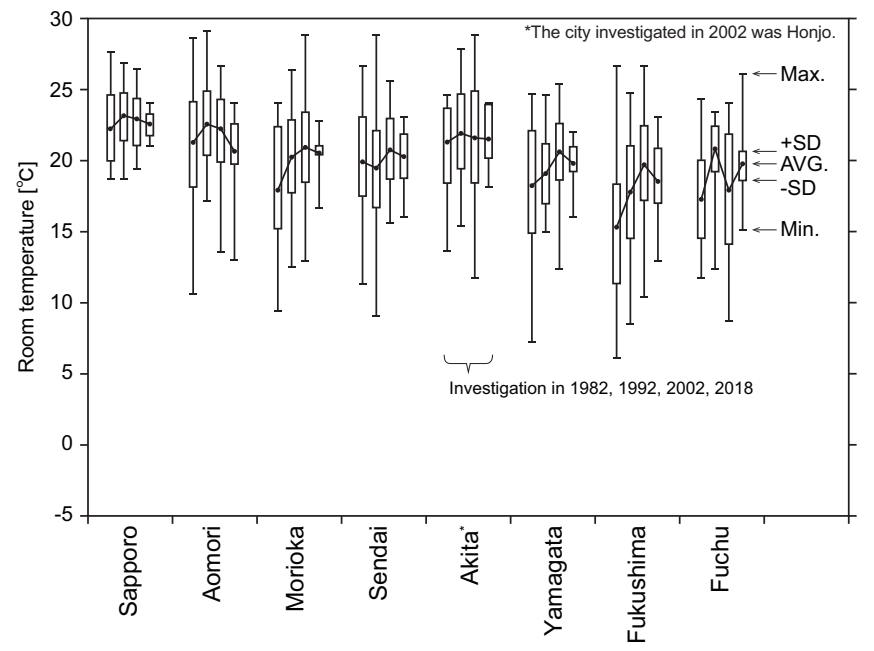

Fig. 3 Statistical values of living room temperature

各都市における朝と夜の居間温度の平均値と調査期間中の平均 外気温との関係を Fig.4 に示す。朝と夜の居間温度は, 外気温が 低い都市ほど高くなる傾向がある。朝の方が回帰直線の傾きが大き く, 札幌を含めて外気温が低い地域ほど居間の温度が高いのは興 味深いところである。朝の居間温度の結果には，寒い地域ほど暖房 を行うことや，住宅の断熱性能が高いことが反映されているものと推 察される。夜の居間温度では回帰直線の経年変化は小さいが, こ れは, いずれの調查年においても, この時間帯では大半の世帯で 暖房しているためと考えられる。一方, 朝の居間温度に対寸る調査 年ごとの回帰直線の差は大きく, これは, 調査対象とした都市全体 において住宅の断熱性能や暖房運転の状況が変化していることを示 すものと考えられる。

\section{4. 室温と暖房エネルギー消費量に及ぼす影響要因の分析 \\ 4.1 分析概要}

各世帯の「朝の居間温度」と「暖房エネルギー消費量」にはば らつきが大きいことが確認されたため，これらのばらつきの原因とな る影響要因を統計的に明らかにする。本研究で扱うデータは, 地域 として 8 都市を選定し, それぞれの都市に居住する世帯より得られ たものである。従って，データが階層性を有するとすれば，室温や エネルギー消費量に影響する要因には, 「都市間の影響」と「世帯 間の影響」が混在していると考えられる。このような階層性を有寸る データを適切に扱うためには，都市間と世帯間の効果を区別した分 析が可能な「マルチレベルモデル」を用いることが有効である ${ }^{8), 99}$ 本研究では, 回帰分析を階層データに対応させた階層線型モデル （以降，HLM: Hierarchical Linear Modeling) を用いる。

HLMを用いた要因分析では,「朝の居間温度」と「暖房エネルギー 消費量」を目的変数とし，説明変数を目的変数に関連深いと考えら れる 34 項目注7)の中から選択して回帰モデルを作成する。分析対 象の住宅は, データの欠落のない 88 件 (「朝の居間温度」の分析) と 171 件 (「暖房エネルギー消費量」の分析) である。モデルの作 成に当たっては, 事前に, データの階層性の有無を確認して HLM を用いることの妥当性を判断する必要がある。そのために，目的変 数を「朝の居間温度」と「暖房エネルギー消費量」とし, 説明変

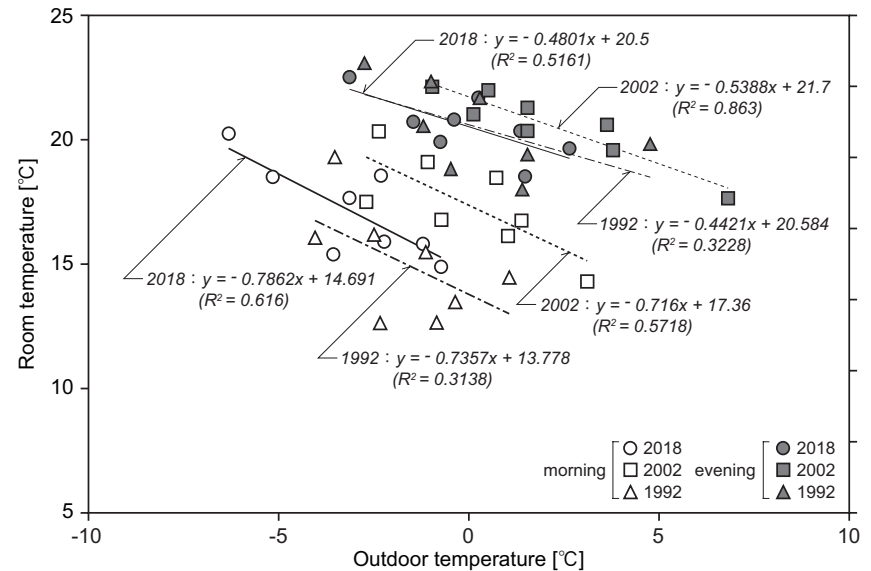

Fig.4 Indoor temperature and outdoor temperature in each city

Table 3 Null model of morning living room temperature

\begin{tabular}{|c|c|c|c|c|c|c|}
\hline \multicolumn{3}{|c|}{ Null model } & \multirow{2}{*}{$\begin{array}{r}\text { Estimate }\left[{ }^{\circ} \mathrm{C}\right] \\
17.03\end{array}$} & \multirow{2}{*}{\multicolumn{2}{|c|}{$\begin{array}{r}\text { Standard Error } \\
0.69 \\
\end{array}$}} & \multirow{2}{*}{$\frac{p \text {-value }}{* * *}$} \\
\hline Fixing Effect & Intercept & & & & & \\
\hline \multirow{2}{*}{ Random Effect } & \multirow{2}{*}{\multicolumn{2}{|c|}{$\begin{array}{l}\text { Variance of Residual } \\
\text { Variance of Intercept }\end{array}$}} & 23.44 & & 1.35 & $\star \star \star *$ \\
\hline & & & 3.49 & & 2.02 & * \\
\hline \multicolumn{2}{|c|}{-2 $2 \times$ Logarithm Likelihood (-2LL) } & 3691.21 & \multicolumn{2}{|l|}{ Parameter } & & 3 \\
\hline \multicolumn{2}{|c|}{ Akaike's Information Criterion (AIC) } & 3695.21 & \multicolumn{2}{|l|}{ Frequency } & & 616 \\
\hline \multicolumn{2}{|c|}{ Corrected AIC of Hurvich and Tsai (AICC) } & 3695.23 & \multirow{2}{*}{\multicolumn{2}{|c|}{$\begin{array}{l}\text { Intra-class Correlation } \\
\text { Coefficient }\end{array}$}} & & \multirow{2}{*}{0.130} \\
\hline \multicolumn{2}{|c|}{ Consistent AIC of Bozdogan (AICC) } & 3706.04 & & & & \\
\hline Bayesian Information C & $n(B I C)$ & 3704.04 & \multicolumn{2}{|l|}{ Design Effect } & & 10.79 \\
\hline
\end{tabular}

Table 4 Null model of annual energy consumption

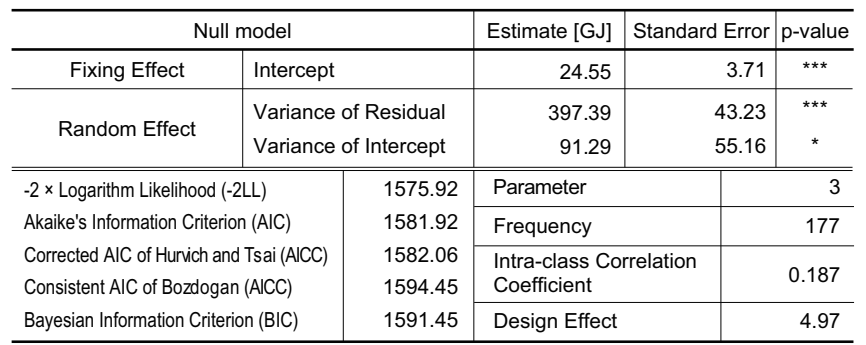

数を投入しないヌルモデルを作成し，級内相関係数注 8$)$ とデザインイ フェクト注8) を評価した。また, 最終モデルの構築に使用する説明変 数に対して相関分析を行い, 多重共線性を考慮するため, 強い相 関を有する項目を説明変数から省くようにした。その上で，世帯レ 
Table 5 Analyzed results of temperature in a living room from the multilevel modelings

\begin{tabular}{|c|c|c|c|c|c|c|}
\hline \multicolumn{4}{|c|}{ Final model } & Estimate $\left[{ }^{\circ} \mathrm{C}\right]$ & Standard Error & $p$-value \\
\hline \multirow{11}{*}{ 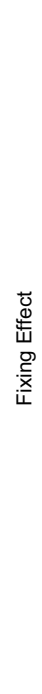 } & \multicolumn{3}{|c|}{ Intercept } & 17.72 & 0.54 & $* \star *$ \\
\hline & \multirow{9}{*}{ 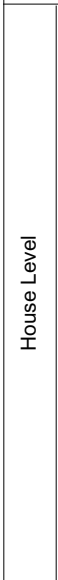 } & \multicolumn{2}{|c|}{$\begin{array}{l}\text { Energy consumption } \\
\text { [Heating energy consumption in each house (GJ)] }\end{array}$} & 0.06 & 0.01 & *** \\
\hline & & \multicolumn{2}{|l|}{$\begin{array}{l}\text { Sunshine condition } \\
\text { [1:Good / 2:Bad] }\end{array}$} & -1.56 & 0.49 & ** \\
\hline & & \multicolumn{2}{|c|}{$\begin{array}{l}\text { Room air conditioning } \\
\text { [Dummy variable (Not using:0 / Using:1)] }\end{array}$} & -2.15 & 0.41 & $\star * *$ \\
\hline & & \multicolumn{2}{|c|}{$\begin{array}{l}\text { Heating period } \\
\text { [Period of using heating equipment (months)] }\end{array}$} & -0.67 & 0.19 & $\star \star \star *$ \\
\hline & & \multicolumn{2}{|c|}{$\begin{array}{l}\text { Pattern of heating time } \\
\text { [1:All the time } / 2 \text { :From the morning to evening } / 3: \ln \\
\text { the morning, noon and evening } / 4 \text { :In the morning and } \\
\text { evening } / 5: \ln \text { the evening } / 6: \text { During the sleeping time] }\end{array}$} & -0.86 & 0.17 & $* \star \star$ \\
\hline & & \multicolumn{2}{|c|}{$\begin{array}{l}\text { Thermal environment in the morning } \\
\text { [1:Extremely cold / 2:Cold / 3:A little cold } \\
\text { 4:Moderate humidity / } 5: A \text { little hot] }\end{array}$} & 1.90 & 0.24 & $\star * \star *$ \\
\hline & & \multicolumn{2}{|c|}{$\begin{array}{l}\text { Perception of dryness } \\
\text { [1:Extremely dryness / } 2 \text { :A little dryness } \\
\text { 3:Moderate humidity / } 4: A \text { little dampness } \\
\text { 5:Extremely dampness] }\end{array}$} & 0.85 & 0.30 & $\star \star \star *$ \\
\hline & & \multicolumn{2}{|c|}{$\begin{array}{l}\text { Perception of air contamination } \\
\text { [1:Always feeling / 2:Frequently feeling } \\
\text { 3:Not feeling] }\end{array}$} & -2.60 & 0.38 & ** \\
\hline & & \multicolumn{2}{|c|}{$\begin{array}{l}\text { Age } \\
{[1: 20 \mathrm{~s} / 2: 30 \mathrm{~s} / 3: 40 \mathrm{~s} / 4: 50 \mathrm{~s} / 5: 60 \mathrm{~s}]}\end{array}$} & 1.21 & 0.32 & $* \star *$ \\
\hline & : & \multicolumn{2}{|c|}{$\begin{array}{l}\text { Windows pane } \\
\text { [1:Single pane / 2:Double pane / 3:Double windows } \\
\text { 4:Triple pane] }\end{array}$} & 6.84 & 2.58 & ** \\
\hline \multirow{4}{*}{\multicolumn{2}{|c|}{ 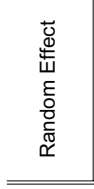 }} & \multicolumn{2}{|l|}{ Variance of Residual } & 9.57 & 0.75 & $* \star *$ \\
\hline & & \multicolumn{2}{|l|}{ Variance of Intercept } & 2.20 & 1.27 & $\dagger$ \\
\hline & & \multicolumn{2}{|c|}{$\begin{array}{l}\text { Covariance of Intercept and } \\
\text { Average Outdoor temperature in the morning }\end{array}$} & 0.07 & 0.08 & \\
\hline & & \multicolumn{2}{|c|}{$\begin{array}{l}\text { Variance of Average Outdoor temperature } \\
\text { in the morning }\end{array}$} & $.0027 \mathrm{~b}$ & 0.00 & \\
\hline \multirow{5}{*}{\multicolumn{3}{|c|}{$\begin{array}{l}-2 \times \text { Logarithm Likelihood (-2LL) } \\
\text { Akaike's Information Criterion (AIC) } \\
\text { Corrected AIC of Hurvich and Tsai (AICC) } \\
\text { Consistent AIC of Bozdogan (AICC) } \\
\text { Bayesian Information Criterion (BIC) }\end{array}$}} & 1721.9 & \multicolumn{2}{|l|}{ Parameter } & 15 \\
\hline & & & 1751.9 & \multirow{2}{*}{\multicolumn{2}{|c|}{ Frequency }} & 616 \\
\hline & & & 1753.5 & \multirow{3}{*}{\multicolumn{3}{|c|}{$\begin{array}{l}b: \text { This covariance is verbose. } \\
{ }^{* \star \star} p<0.01,{ }^{\star \star} p<0.05, \dagger \quad p<0.10\end{array}$}} \\
\hline & & & 1824.1 & & & \\
\hline & & & 1809.1 & & & \\
\hline
\end{tabular}

ベルが都市レベルに包含される階層構造が存在することを想定しな がら，変量効果には都市間の特徵を代表する変数として都市の調査 期間中の外気温を用い，最も適合度の高い説明変数を投入注9) した 結果を最終モデルとした。なお，分析には，IBM SPSS Statistics Ver.24を使用した。

\section{2 ヌルモデルによるデータの階層性の確認}

「朝の居間温度」と「暖房エネルギー消費量」のヌルモデルを Table 3 とTable 4 に示す。いずれの目的変数についても, 級内

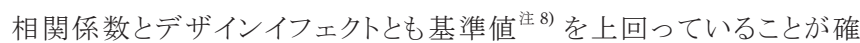
認できる。従って, いずれの目的変数にも集団類似性が認められ, 都市内の世帯間には共通性があるとともに都市間の変動が大きいと いう，階層的データの特徴が確認できたため，HLM を適用すること が妥当だと判断できる。

\section{3 朝の居間温度の最終モデル}

HLM による最終モデルを Table 5 に示す。

固定効果の世帯レベルの項目を見ると，「朝の居間温度」のばら つきの要因が確認できる。「エネルギー消費量」（p<0.001）の影響 は大きいとはいえないが，消費量が多いほど「朝の居間温度」は 高くなる。「日照条件」（p<0.01）では，日当たりが良いと回答した 世帯では「朝の居間温度」が $1.56{ }^{\circ} \mathrm{C}$ 高い。また，暖房器具として 「エアコン」 $(\mathrm{p}<0.001)$ を使用している世帯の方が「朝の居間温度」 が低いことが示され，「暖房期間」（ $\mathrm{p}<0.001 ）$ が短いほど，「暖房時 間」 $(\mathrm{p}<0.001)$ が長いほど,「朝の居間温度」が高くなる傾向がある。 室内環境に関する項目では，「起床時の寒さ」（p<0.001）を感じる ほど「朝の居間温度」が低く, 「室内の乾燥」（ $\mathrm{p}<0.01 ）$ や「空気
Table 6 Analyzed results of annual energy consumption from the multilevel modelings

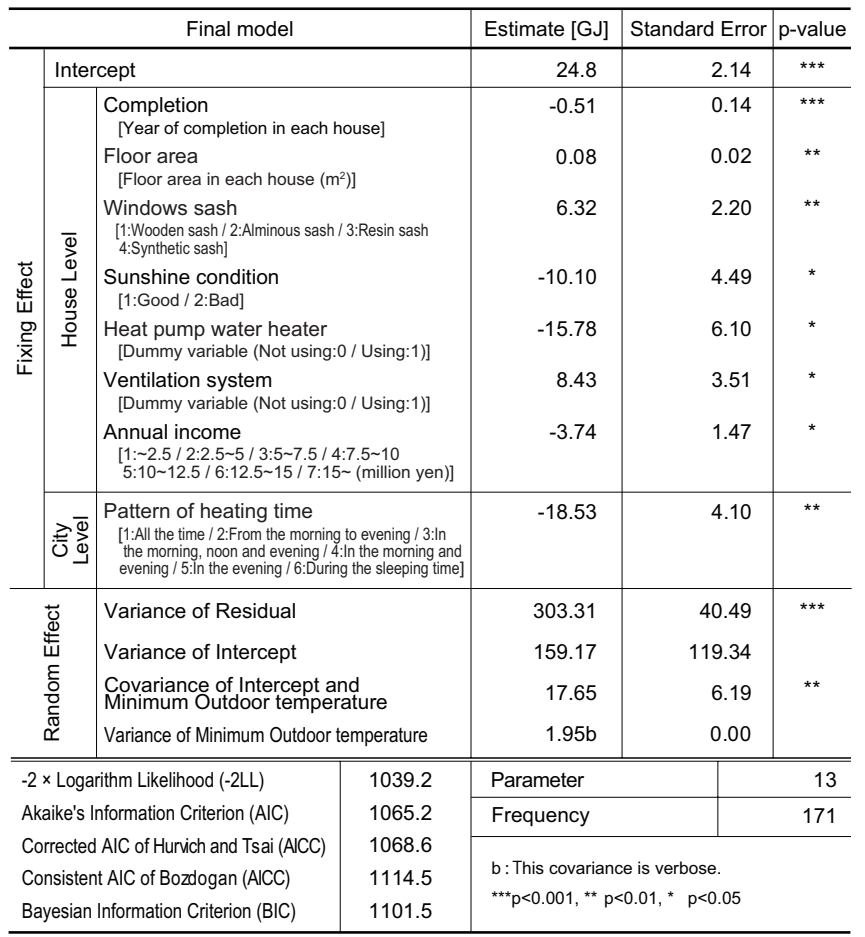

の污れ」（p<0.001）を感じている世帯ほど「朝の居間温度」が高い 結果となった。室内環境の質に対する評価が温度と関連しており, これらの要因による温度変動の幅は $0.85 \sim 2.61^{\circ} \mathrm{C}$ 範囲にある。 居住者特性として, 「回答者年齢」（p<0.001）が高いほど「朝の居 間温度」は高くなる傾向がある。

固定効果の都市レベルの項目では, 「密ガラスの枚数」が有意 ( $\mathrm{p}<0.01)$ であり, 枚数が多い住宅の頻度が高い都市ほど「朝の居 間温度」が高くなる傾向がある。また, 変量効果として, 切片の分 散のみが有意 $(\mathrm{p}<0.1)$ であることから, 各都市における「朝の居間 温度」の平均值が都市によって異なることが確認され, それは「空 ガラスの枚数」, すなわち断熱性能の影響が大きいことが示唆される。

\section{4 暖房エネルギー消費量の最終モデル}

HLM による最終モデルを Table 6 に示す。

固定効果のうち，世帯レベルの項目は「暖房エネルギー消費量」 のばらつきを説明している。「住宅竣工年」（p<0.001）が新しいほ ぞ「暖房エネルギー消費量」は少ない傾向にあり, 高い断熱性能 や高効率設備の導入が影響している可能性が窥える。また，「床面 積」( $<<0.01)$ や照条件」（ $<<0.05 ）$ は「暖房エネルギー消費量」 のばらつきに影響する要因の一つである。「空サッシ」（ $\mathrm{p}<0.01 ） の$ 断熱性が高いほど「暖房エネルギー消費量」は大きくなり, 暖房器 具として「HP 温水暖房」 $(\mathrm{p}<0.05)$ を利用した場合, 「暖房エネルギー 消費量」を $15.78 \mathrm{GJ}$ 削減する効果をもたらすことになる。「換気設 備」（p<0.05）を使用している世帯の方が「暖房エネルギー消費量」 が多くなっているが，計画的な換気による熱負荷の増大が抑制され ていない可能性が示唆される。既往の調査例えば10) では, 世帯年収 が多くなるほど年間エネルギー消費量が多い傾向が認められるが, その影響は小さいことが示されている。本論文で対象としている地域 の標準的な世帯属性に限定した範囲では, 「年間収入」（p<0.05） が多いほど「暖房エネルギー消費量」が少なくなっており, 省エネ 
ルギーに寄与する住宅性能が高いことにも関連すると推察されるが, 理由は明らかでない。

固定効果における都市レベルの結果では，「暖房時間」が有意 $(\mathrm{p}<0.01)$ となり, 時間が短い住宅が多い都市ほど「暖房エネルギー 消費量」が少なくなることが示される。変量効果では, 切片と「最 低外気温」のいずれも有意ではなかったが，両者の共分散が有意 $(\mathrm{p}<0.01)$, かつ正の值になっている。よって, 札幌や北東北の都 市のように, 「暖房エネルギー消費量」の平均值が高い都市では「最 低外気温」の影響を受けや寸く、「暖房エネルギー消費量」の平均 值が小さい都市では, 「最低外気温」の影響を受けにくい傾向にあ ることが示唆される。

\section{5. 熱環境からみた居住性能に関する地域特性の分析}

\section{1 分析概要}

東北地方の地域特性を明らかにするため, Table 7 に示す 16 因 子 58 カテゴリーを対象として多重コレスポンデンス分析注 ${ }^{10)}$ を行い, 587 件の調查データを用いた。分析には, IBM SPSS Statistics Ver.24 使用した。

\section{2 分析結果}

(1)シェルター性能に関する因子を用いた分析

Table 7 のシェルター性能に関する因子を用いて分析した。結果 をFig.5 に示す。図では,「住宅竣工年」のカテゴリーを直線で結 んでいる。

カテゴリー散布図 (Fig.5(a)) によると，I 軸の正の象限に「1 枚 ガラス」「木製サッシ」「アルミサッシ」, 負の象限に「樹脂サッシ」

「複合サッシ」「3 枚ガラス」などのカテゴリーが分布しているため, I 軸はシェルター性能の優劣を表すと考えられる。一方，II 軸には， 明確な特徴は見られない。この傾向は過去に示した分析結果と同様 1) 3) である。カテゴリースコアが近く, 関係性が高いと考えられるカ テゴリーグループは, 「2010 年代建設」「100-140m²」「樹脂サッシ」

「複合サッシ」「2 枚サッシ」のグループと,「1990 年代建設」「1980 年代建設」「2 枚サッシ」「アルミサッシ」のグループなどが挙げられ， 新しい住宅であるほど性能が高いことが読み取れる。

(a) Scatter diagram of categories (II)

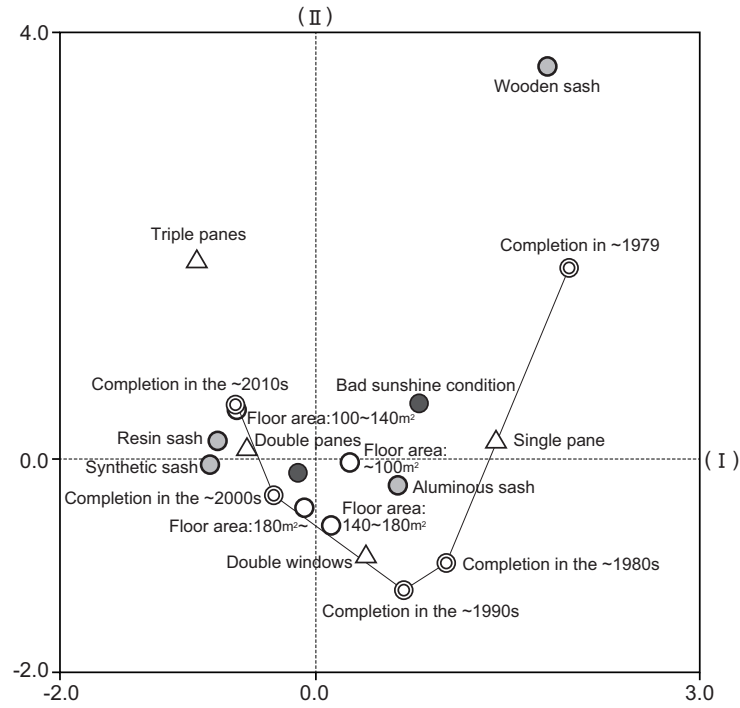

Fig.5 Analyzed results of shelter performance from multiple correspondence analysis
各都市の世帯のばらつきの範囲 (Fig.5(b)) を見ると, 2002 年ま での分析結果では, 札幌の範囲はシェルター性能が優れている象 限に, 東北地方の各都市は広範囲に分布し, 両者の差が明確であっ た。しかしながら, 今回の結果では, 原点付近で重なっており, シェ ルター性能の差が曖昧になっている。また, II 軸の負の象限では, 全ての都市の範囲がほぼ一致していることから，2002 年の調査時 点以降, 地域に関係なく一定水準以上のシェルター性能が確保さ れつつあることが予想される。一方で, 青森, 盛岡, 秋田はばらつ きが大きいが，「木製サッシ」の影響が大きいと考えられる。

\section{(2)暖房環境に関する因子を用いた分析}

Table 7 の暖房環境に関する因子を用いて分析した結果をFig.6 に示す。図では, 「朝の居間温度」「暖房エネルギー消費量」のカ テゴリーを直線で結んでいる。

カテゴリー散布図 (Fig.6(a)) によると, I 軸の正の值が大きい範 囲に「80GJ 以上」「60〜80GJ」, 原点付近に「20GJ以下」の力 テゴリーが分布していることから，I 軸はエネルギー消費量の大小を 表していると考えられる。一方, II 軸に関しては正の象限に「就寝

Table 7 Items used in multiple correspondence analysis

\begin{tabular}{|c|c|c|c|c|c|}
\hline \multirow{2}{*}{ Factor } & \multirow{2}{*}{\multicolumn{2}{|c|}{ Item and No. of categories }} & \multicolumn{3}{|c|}{ Analysis* } \\
\hline & & & $(1)$ & $(2)$ & (3) \\
\hline \multirow{5}{*}{$\begin{array}{l}\text { Shelter } \\
\text { performance }\end{array}$} & 1) Completion & 5 & $x$ & & $x$ \\
\hline & 2) Floor area & 4 & $x$ & & $x$ \\
\hline & 3) Window flame & 4 & $x$ & & $x$ \\
\hline & 4) Window pane & 4 & $x$ & & $x$ \\
\hline & 5) Sunshine condition & 2 & $x$ & & $x$ \\
\hline \multirow{4}{*}{$\begin{array}{l}\text { Thermal } \\
\text { environment } \\
\text { and IAQ }\end{array}$} & 6) Morning living room temperature & 4 & & $x$ & $\mathrm{x}$ \\
\hline & 7) Evening living room temperature & 2 & & $x$ & $x$ \\
\hline & 8) Perception of indoor air contamination & 3 & & & $x$ \\
\hline & 9) Observation of vapor condensation & 2 & & & $\mathrm{x}$ \\
\hline $\begin{array}{l}\text { Energy } \\
\text { consumption }\end{array}$ & $\begin{array}{l}\text { 10) Annual energy consumption } \\
\text { for space heating }\end{array}$ & 5 & & $x$ & $x$ \\
\hline \multirow{3}{*}{ Equipment } & 11) Heating equipment & 6 & & $\mathrm{x}$ & $x$ \\
\hline & 12) Auxiliary heating equipment & 2 & & $x$ & $x$ \\
\hline & 13) Midnight power service & 2 & & $x$ & $x$ \\
\hline \multirow{2}{*}{$\begin{array}{l}\text { Occupant } \\
\text { behavior }\end{array}$} & 14) Heating period & 3 & & $x$ & $x$ \\
\hline & 15) Heating time & 6 & & $x$ & $x$ \\
\hline $\begin{array}{l}\text { Household } \\
\text { information }\end{array}$ & 16) Annual income & 4 & & & $x$ \\
\hline
\end{tabular}

* (1) Shelter performance; (2) Thermal environment during heating period;

(3) Winter thermal performance and occupants behavior

(b) Scatter diagram of houses in each city

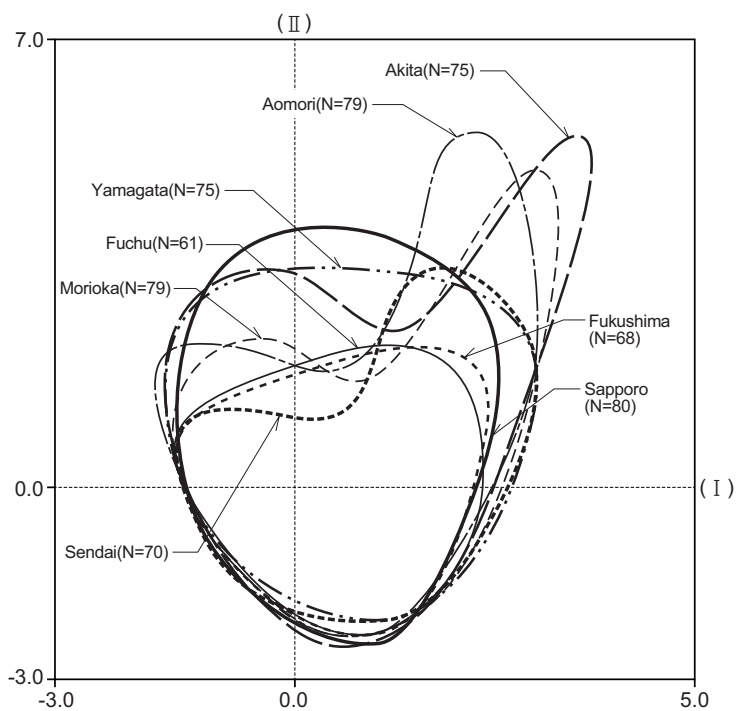


(a) Scatter diagram of categories

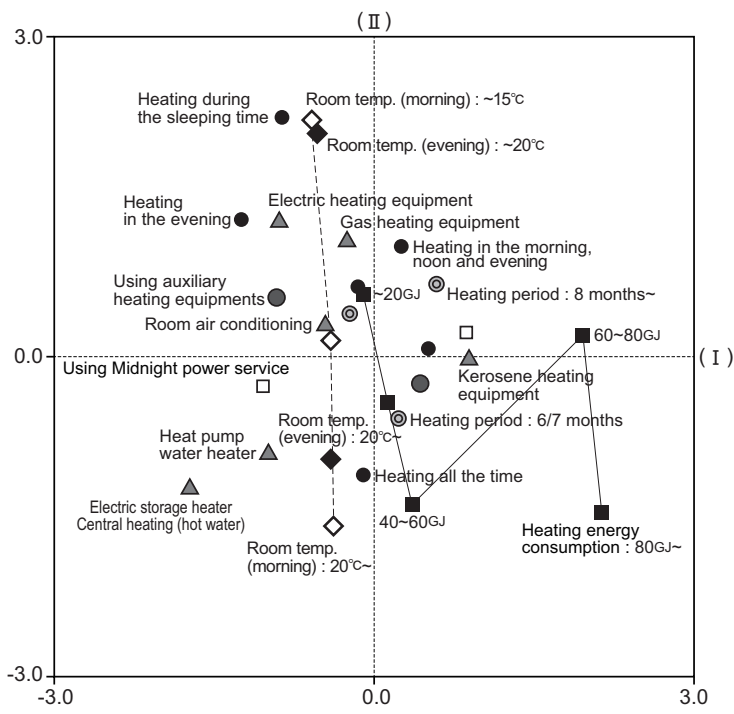

(b) Scatter diagram of houses in each city

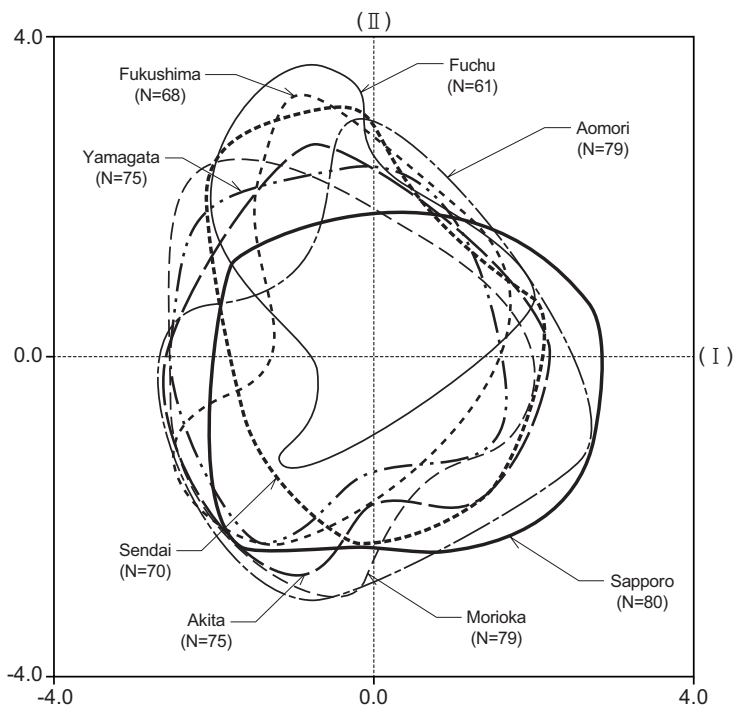

Fig.6 Analyzed results of thermal environment during heating period from multiple correspondence analysis

(a) Scatter diagram of categories

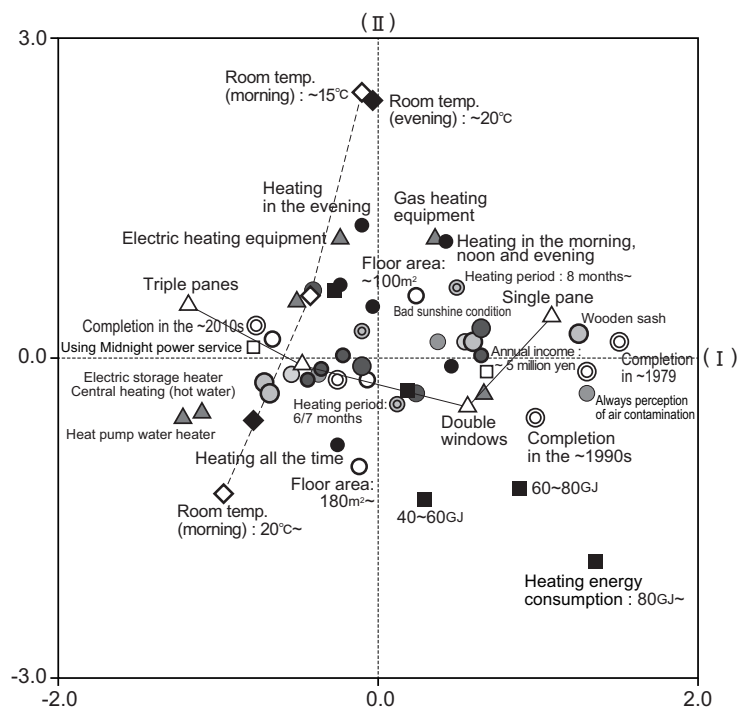

(b) Scatter diagram of houses in each city

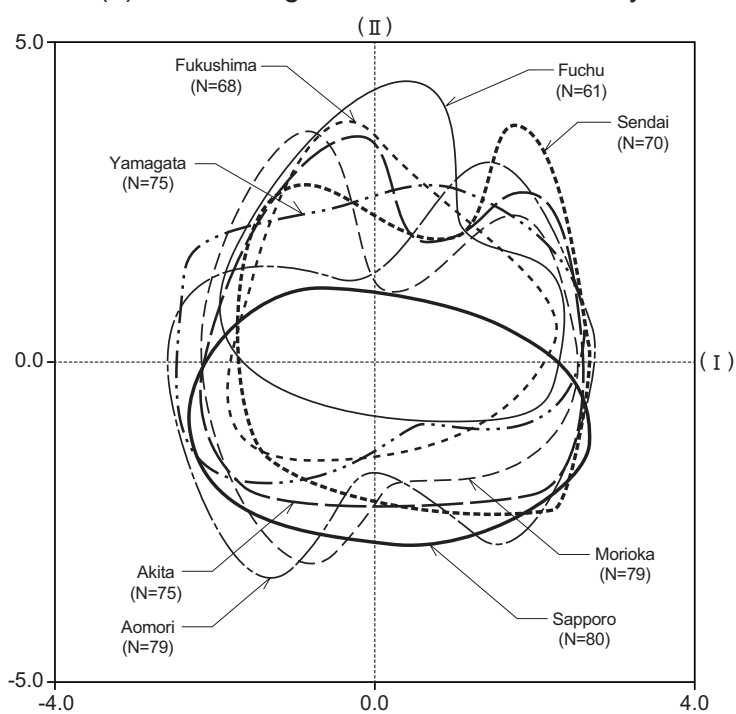

Fig.7 Analyzed results of winter thermal performance and occupnats behavior from multiple correspondence analysis

時暖房」「朝 $15^{\circ} \mathrm{C}$ 未満」「夜 $20^{\circ} \mathrm{C}$ 未満」, 負の象限に「朝 $20^{\circ} \mathrm{C}$ 以 上」「夜 $20^{\circ} \mathrm{C}$ 以上」のカテゴリーが分布しているため， II 軸は室温 の高低を表している。居間の暖房時間では，II 軸の正の側に暖房 時間が短い，負の側に長いカテゴリーが布置されているため，暖房 時間はエネルギー消費量よりも室温と関係しているといえる。カテゴ リースコアが近く, 関係性が高いと考えられるカテゴリーグループは,

「就寝時暖房」「朝 $15^{\circ} \mathrm{C}$ 未満」「夜 $20^{\circ} \mathrm{C}$ 未満」「夕食 - 就寝暖房」「電 気暖房」のグループと,「朝 $20^{\circ} \mathrm{C}$ 以上」「終日暖房」「夜 $20^{\circ} \mathrm{C}$ 以上」

「HP 温水暖房」のグループなどが挙げられる。また，カテゴリー 間の距離が長い因子は,「暖房時間」「室温」「暖房器具」であり, これらは世帯の分布へ強く影響すると推察される。

各都市のばらつきの範囲 (Fig.6(b)) について, 2002 年の分析結 果では, i) 青森, 本荘注 ${ }^{11)}$, ii) 福島, iii) 盛岡, 仙台, 山形の 3 つのグループに区別されたが，1982 年や 1992 年の分析結果よりも ばらつきが大きく暖房環境の地域性が曖昧になる傾向を確認した。 今回の分析結果では, 府中が II 軸の正の範囲に多く分布しているも
のの, 2002 年よりもさらに地域性は曖昧になり, 各都市の暖房環境 が類似しつつあることが確認できる。

\section{(3)居住性能に関する因子を用いた分析}

Table7 の居住性能に関する因子を用いて分析した。結果を Fig.7 に示す。図では, 「朝の居間温度」と「空ガラスの枚数」の カテゴリーを直線で結んでいる。

カテゴリー散布図 (Fig.7 (a)) によると, I 軸の正の象限に「1 枚 ガラス」, 負の象限に「3 枚ガラス」が分布していることより, I 軸は シェルター性能の良否を代表していると考えられる。一方, II 軸で は, 正の象限に「夕食 - 就寝暖房」「朝 $15^{\circ} \mathrm{C}$ 未満」, 負の象限に「朝 $20^{\circ} \mathrm{C}$ 以上」「終日暖房」などが分布しており, 室温の高低や暖房時 間を表していると考えられる。エネルギー消費量は,「80GJ 以上」 が分布する第 4 象限から第 2 象限に向かって小さくなる傾向が確認 でき, シェルター性能と居間温度が関連していると考えられる。カテ ゴリースコアが近く, 関係性が高いと考えられるカテゴリーグループ は, 「朝 $20^{\circ} \mathrm{C}$ 以上」「終日暖房」「 $\mathrm{HP}$ 温水暖房」のグループと, 
「朝 $15^{\circ} \mathrm{C}$ 未満」「夜 $20^{\circ} \mathrm{C}$ 未満」のグループが挙げられ, 室内環境 の水準が低く, エネルギー消費量が少ないカテゴリーが II 軸の正の 象限, 室内環境の水準が高く, 灯油暖房以外の高効率暖房のカテ ゴリーが II 軸の負の象限に分布している。また，カテゴリー間の距 離が長い因子は,「住宅竣工年」「室温」「空ガラスの枚数」「エネ ルギー消費量」などであり，世帯の分布に影響すると考えられる。

2002 年の分析結果では地域の差が以前よりも曖昧になりつつあっ たが, 札幌の分布の様子は, 他の都市とは明らかに異なっていた。 今回 (Fig.7(b)) は, 札幌も含めて, さらに地域の差が曖昧になっ た。しかしながら，札幌は比較的ばらつきが小さいが，府中市はII 軸の正の象限に偏っており全体的に室温が低いこと, 東北地方の都 市では相対的にばらつきが大きいことがわかる。よって，都市間の 差は小さいが，概ね以下のグループに分類できそうである。i）札幌 の居住性能に類似しているが, ばらつきが大きい青森, 盛岡, 秋田, 山形，ii） i）に類似し，「空ガラスの枚数」に代表されるような断熱 性能が低い世帯を含む仙台, iii) 府中に近い, 福島。今回の結果 では，全ての都市が札幌市の分布と重なる範囲が存在しており，冬 期の居住性能が札幌に近づきつつあるといえるが，依然として地域 内でのばらつきは大きい。

\section{6. まとめ}

東北地方都市部の住宅を対象に居住性能に関するアンケート調査 と室温調查を行い, 過去の調查結果と比較するとともに, 地域特性を 統計的に分析した。その結果，以下のことが明らかとなった。

(1) 36年間で居住性能は大きく変化し, 東北地方においては「二枚ガ ラス」の割合が高くなるなど, 断熱性能の向上が確認できる。暖房 器具として石油暖房の使用割合が減少し, エアコンを始めとする 電気を熱源とする機器が増加する一方で, こたつの使用割合は 2002 年調查時点の半分以下となった。また,「暖房時間」は増加 傾向にある。

(2) 各都市の灯油消費量は 2002 年と比較すると減少している。この理 由として, 断熱性能の向上がその一因として考えられる。一方, 各 都市の暖房エネルギー消費量における世帯間のばらつきは非常 に大きい。

(3) 液晶温度計による朝の居間温度の平均值は $17.1^{\circ} \mathrm{C}$ であり, 2002 年の調查よりも $1^{\circ} \mathrm{C}$ 程度上昇している。各都市間の温度差は小さく なり，上昇傾向は頭打ちになりつつあるものの，住戸間のばらつき は大きい。また, 朝と夜の居間温度は, 外気温が低い都市ほど高 くなる傾向があり, 寒冷な地域ほど防寒に対する意識が高く, 室 内温度を適切に維持していると考えられる。

(4) データの階層性を考慮したマルチレベル分析を行い, 朝の居間 温度と暖房エネルギー消費量について都市間と世帯間のばらつ きに寄与する因子を評価した。朝の居間温度は, エネルギー消費 量, 日照条件, 暖房機器の種類, 暖房時間の他, 室内環境に対 する乾燥感や空気の污れが室温と関連が深い。いずれの都市に おいても空ガラスの枚数に代表される断熱性能が高いほど, 朝の 居間温度が高い。暖房エネルギー消費量では, 竣工年, 延心゙床 面積, 空サッシや暖房機器の種類, 暖房時間などが影響要因で あった。また, 寒冷な都市ほど暖房エネルギー消費量の平均值が 高く, 最低外気温の影響を受けやすいことが示された。
(5) 東北地方都市部の住戸の居住性能は, これまでの調査で確認さ れたような札幌市との明確な差は曖昧になり, 都市間の差は小さ くなった。特に, 北東北の都市の居住性能が札幌市に近づいて いることが明らかとなった。その上で, 概ね以下のグループに分類 できそうである。i) 札幌の居住性能に類似しているが，ばらつきが 大きい青森, 盛岡, 秋田, 山形, ii) i) に類似し, エネルギー消費 量が高い世帯を含む仙台, iii) 府中に近い, 福島。今回の結果で は, 全ての都市が札幌市の分布と重なる範囲が存在しており, 冬 期の居住性能が札幌に近づきつつあるといえる。しかしながら，依 然として世帯間のばらつきは大きく, 水準の低い住宅の居住性能 を高めるために, 各地域に応じた対策を提示していく必要がある。

\section{謝辞}

本研究は, 公益財団法人 LIXIL 住生活財団による調査助成 (助 成番号 17-32) の補助により実施したものである。本調查を行うにあ たっては, 調査に参加いただいた方々をはじめ, 関係各位に多大 なる協力を得ている。ここに記して, 深甚なる謝意を表する次第であ る。なお, 本調査の実施に対して, 秋田県立大学・倫理審查委員 会の承認 (受付番号第 17-31 号) を得ている。

\section{注}

注 1) 筆者らは, 住宅の熱環境を形成する要素としてのシェルター性能, 設備, 住 まい方，エネルギー消費量，居住者特性，地域条件を総合的に捉え，「熱 環境からみた居住性能」と呼んでいる。

注 2) その時の調查結果によれば，戸建住宅では断熱材の使用割合が増加する傾 向を確認した。北東北地域では, 暖房機器として密閉型, 南東北地域では 開放型を使用寸る割合が高く，特に，朝の室温上昇が大きかった。また，居 間での結露発生を 6 割程度の住宅で申告しており，10 年前の結果よりも増加 していた。一冬の灯油消費量では, 調查件数が極端に少ない ( 各都市 10 世 帯程度) ものの, 札幌と八戸にてやや増加, 盛岡, 秋田, 山形, 酒田, 仙台, 府中ではやや減少傾向であった。

注 3) 対象都市は下図の通り, 東北地方 6 都市 (2002 年の調查で対象とした旧本 荘市を除く) と札幌市，府中市である。

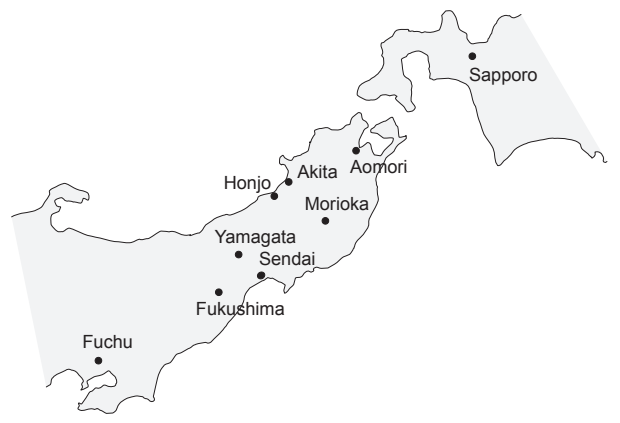

注 4) 国内に約 1,300 万人の一般モニターを有し，男女比は 1:0.89, 10 代から 70 代までの年齢層を網羅している。

注 5) 縦 $10 \mathrm{~cm}$, 横 $15 \mathrm{~cm}$, 厚さ $0.5 \mathrm{~cm}$ の断熱材に温度表示部分を貼り付けたもの である。測定範囲は $-6 \sim 30^{\circ} \mathrm{C}$, 目盛りの表示は $2^{\circ} \mathrm{C}$ 刻み (読み取りは $1^{\circ} \mathrm{C}$ 刻み で可能)である。また，読み取り精度は文献1)において検討した通り，測温 抵抗体による測定值と土 $2^{\circ} \mathrm{C}$ 範囲で概初一致しており, 地域的な差を把握 することを目的とする本調查にて用いるには問題ないものと考えられる。

注 6) 灯油消費量に対しては, 暖房用燃料として「一冬の使用量はどれくらいですか」 といら質問への回答をもとにしている。暖房用に電気を使用している世帯に対 しては, 平成 29 年の月毎の電力消費量を用いて, 非暖房期間の使用量を差 し引いて暖房用を推定した。なお，本調査では，ガスを燃料とする暖房器具 を主に使用している世帯を含めていない。

注 7) Table 2 の下線に示した項目より, 次の説明変数を選択した。【室内環境 (4 変数)】朝の平均居間温度; 朝の寒さ; 乾燥の感じ方; 空気の污れの感じ方 ／住宅設備 (13 変数)】次の暖房器具の使用有無 (居間) : 灯油暖房, 
ガス暖房, 電気暖房, エアコン, HP 温水暖房, 蓄熱式暖房 ; 主暖房器具 の種類 ; 補助暖房の有無 ; 寝室の暖房器具 ; 電球の種類 ; 換気設備の有無 ; 給湯設備の種類; 深夜電力利用の有無 【【住まい方 (4 変数)】暖房期間 ; 居間の暖房時間; 寝室の暖房時間; 子供室の暖房時間／【シェルター性能 (7 変数)】住宅竣工年 ; 延床面積 ; 居室の数 ; 空サッシの種類 ; 空ガラスの枚 数; 断熱等級; 日照の良否 【【エネルギー消費量 (1 変数)】暖房エネル ギ一消費量【【居住者特性 (5 変数)】年間収入; 回答者の年齢; 家族人数; 男性の着衣量 ; 女性の着衣量

注 8) 級内相関係数 (ICC) は，集団内の類似性を評価する指標である。ICC が大 きければデータに集団内類似性が存在することになる。データの階層性の判 断はICC が 0.1 以上といわれている。また，デザインイフェクト (DE) が 2 以 上の場合に，データに階層性があると判断される。

注 9) 世帯毎に得られたアンケートの回答を世帯レベルの変数として扱う場合には, 都市を集団として集団平均中心化して説明変数とした。また，これらを都市レ ベルの変数として扱う場合には, 各都市の平均值を全体平均中心化した。こ の他, 都市レベルの変数には, 「朝の平均外気温」や「最低外気温」なども あるが，これらも同様に全体平均中心化して説明変数とした。

注 10)3 つ以上の質的変数を用いて各カテゴリをマッピングする手法。量的変数を 扱う場合は主成分分析を適用する。

注 11)2002 年の調査では, 秋田市での協力が得られなかったため, 近隣都市であ る本荘市を対象とした。

\section{参考文献}

1) Yoshino, H., Hasegawa, F., Sawada, K., Ishikawa, Y., Akabayashi, S., Kikuta, M. Analysis on regional characteristics of winter thermal performance and occupant's behavior of detached houses in Tohoku city area, Transations of the Architectural Institute of Japan, No. 345, pp.92-103, 1984.11.

吉野博, 長谷川房雄, 沢田紘次, 石川善美, 赤林伸一, 菊田道宣: 熱環境加 みた冬期の居住性能に関する地域特性の分析一東北地方都市部を対象として 一, 日本建築学会論文報告集, 第 345 号, pp.92-103, 1984.11.

2) Yoshino, H., Hasegawa, K. Change in regional characteristics of winter thermal performance and occupant's behavior of detached houses in Tohoku city area for 10 years, Journal of Architecture, Planning and Environmental Engineering (Transactions of AIJ), Vol.62, No. 499, pp.1-7, 1997.9.

吉野博, 長谷川兼一: 熱環境からみた冬期の居住性能に関する地域特性の変 化一東北地方都市部老対象とした 10 年前の調査との比較一, 日本建築学会計 画系論文集,第 62 巻,第 499 号, pp1-7, 1997.9.

3) Hasegawa, K., Yoshino, H., Ishikawa, Y., Matsumoto, S., Genjo, K., Takeuchi, J. Regional characteristics transition of winter thermal performance and occupants' behavior of detached houses in Tohoku city area for 20 years, Journal of Environmental Engineering (Transactions of AIJ), Vol.70, No. 593, pp.33-40, 2005.7.

長谷川兼一，吉野博，石川善美，松本真一，源城かほり，竹内仁哉 : 熱環 境から見た冬期の居住性能に関する地域特性の推移一東北地方都市部を対象 とした 20 年間の変化一, 日本建築学会環境系論文集, 第 70 巻, 第 593 号, pp33-40, 2005.7.

4) Hasegawa, K. Regional characteristics transition of winter thermal performance and occupants' behavior of detached houses in Tohoku city area for 30 years, Jyukankyo Foundation (No. 11-09), pp.1-26. 2013.5.

長谷川兼一: 熱・空気環境から見た冬期の居住性能に関する地域特性の 30 年間の変化, 公益財団法人 LIXIL 住生活財団 研究助成報告書 (助成 No. 11-09), pp.1-26, 2013.5.

5) Ministry of Economy, Trade and Industry. Strategic Energy Plan, 2018.7. 経済産業省 : エネルギー基本計画 (第 5 次 ), 2018.7.

6) Statistic Bureau of Japan. The results of employment status survey, 2013.7. 総務省統計局: 平成 24 年度就業構造基本調査結果, 2013.7.

7) Ikaga, T., Eguchi, R., Murakami, S., Iwamae, A., Hoshi, T., Mizuishi, J., Kawakubo, S., Okumura, K.; Evaluation of investment in residential thermal insulation considering non-energy benefits delivered by health, Journal of Environmental Engineering (Transactions of AIJ), Vol.76, No. 666, pp.735740, 2011.8.

伊香賀俊治, 江口里佳 , 村上周三, 岩前篤, 星旦二, 水石仁, 川久保俊 , 奥村 公美 : 健康維持がもたらす間接的便益 (NEB) を考慮した住宅断熱の投資評価 , 日本建築学会環境系論文集, Vol.76, No.666, pp.735-740, 2011.8

8) Shimizu H. Multilevel Modelings for Individual and Group Data, Nakanishiya Shuppan, 2015.11.
清水裕士 : 個人と集団のマルチレベル分析, ナカニシヤ出版 , 2015.11.

9) Ando, G., Nishina, D., Murakawa, S., Kindaichi, S., Ishida, M., Yasugi, K. Analysis of affecting factors on the energy consumption in detached houses by the multi-level model - Study on the energy consumption of electrified housing in Hiroshima area-, Journal of Environmental Engineering (Transactions of AIJ), Vol.79, No.698, pp.383-392, 2014.4.

安藤元気, 西名大作, 村川三郎, 金田一清香, 石田正樹, 八杉克志 : マルチレ ベルモデルを適用した戸建て住宅におけるエネルギー消費量に及ぼす影響要 因の分析一広島地域の全電化住宅を対象とした電力消費量に関する研究一, 日本建築学会環境系論文集, 第 79 巻, 第 698 号, pp.383-392, 2014.4.

10) Inoue, T., Mizutani, S., Tanaka, T. Energy consumption in housing on the basis of national scale questionnaire, Analysis of influence of various factors on annual energy consumption Part 2, Journal of Environmental Engineering (Transactions of AIJ), Vol.71, No. 606, pp.75-85, 2006.8.

井上隆, 水谷傑纏, 田中俊彦: 全国規模アンケートによる住宅内エネルギー消 費の実態に関する研究, 影響を及ぼす要因に関する分析その 2 , 日本建築学 会環境系論文集, 第 71 巻, 第 606 号, pp.75-85, 2006. 8. 


\title{
REGIONAL CHARACTERISTIC TRANSITIONS OF WINTER THERMAL PERFORMANCE AND OCCUPANT BEHAVIOR \\ OF DETACHED HOUSES IN TOHOKU CITY AREAS OVER 36 YEARS
}

\author{
Kenichi HASEGA WA ${ }^{* 1}$, Sayaka MASUDA ${ }^{* 2}$, Hiroshi YOSHINO ${ }^{* 3}$, \\ Shin-ichi MATSUMOTO*1 and Jinya TAKEUCHI ${ }^{* 4}$

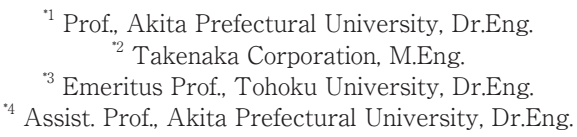

As part of an investigation aimed at gaining a better understanding of indoor thermal environments, energy consumption levels, and occupant behavior, the householders of 587 detached houses in six cities of the Tohoku City region were surveyed in the winter of 2018 via a questionnaire and recorded liquid crystal thermometer measurements. Houses in the cities of Sapporo and Fuchu were used as references. Similar investigations have been performed at 10-year intervals since 1982. The obtained data were then applied to create an overview covering the past 36 years, which resulted in additional information that will be useful for future indoor environmental design. This paper begins by describing wintertime occupant behavior changes and indoor temperature in each city over a 20 -year period and then discusses changes to space-heating energy consumption during the cold winter periods. The influence of various factors on indoor morning temperatures and space heating energy consumption are then analyzed using a multivariate analysis method.

1. The results of this investigation show that the thermal performance levels of houses the Tohoku City region are becoming increasingly similar to those of Sapporo City and that differences among all cities examined have lessened in the last 16 years. In particular, it was confirmed that the thermal performance levels of cities in the northern Tohoku City region had become closer to those of Sapporo City. From the viewpoint of thermal performance levels, these cities can be classified into the following groups: i) the cities of Aomori, Morioka, Akita and Yamagata (which have similar performance levels to Sapporo City); ii) Sendai City (including households with high energy consumption levels); and iii) the cities of Fukushima (which show performance levels similar to Fuchu).

2. The average floor area of Tohoku City detached houses was almost the same as recorded in 2002. Additionally, we found that the use of double windows or double-paned windows has increased among Tohoku region cities since 2002, while heating times have shown overall increasing trends over the last 36 years. Previously, kerosene heaters, including both vented and portable types, were popular among Tohoku region residents, but this investigation found that kerosene heater usage rates have been decreasing since 2002 while the use of electric heaters has increased.

3. Early morning room temperatures have been trending upward for the last 36 years. In fact, the average temperature recorded during this investigation was $17.1^{\circ} \mathrm{C}$, which is a $1.0{ }^{\circ} \mathrm{C}$ increase from 2002 . It is believed that this increase in the early morning temperature level was not only due to improvements resulting from insulation and airtight building envelope conditions, but also due to increased heating times.

4. To clarify the factors influencing morning living room temperatures and energy consumption levels for space heating, a multi-level analysis method was applied. The factors that were considered to influence temperature were sunshine levels, thermal insulation, heating equipment type, heater usage times, morning thermal environment, and indoor humidity level perceptions. As for the dispersion of energy consumption for space heating, the factors considered were sunshine levels, completion, floor area, primary heating equipment, and heater usage times. It was also shown that the average energy consumption for space heating in northern cities was the highest among the cities surveyed, and that room temperatures were less susceptible to outdoor temperature declines due to increased thermal insulation performance levels. 